\title{
Slope stability analysis and landslide susceptibility assessment on the SE foot slopes of Mt Cameroon
}

\author{
Vivian Bih Che
}

Supervisor: Patric Jacobs (1)

Co-supervisors: Emmanuel Suh (2), Matthieu Kervyn (3),Philippe Trefois (4)

(I) Department of Geology and Soil Science, Ghent University

(2) Department of Geology and Environmental Science, University of Buea, SW Cameroon

(3) Department of Geography, Vrije Universiteit Brussels

(4) Department of Earth Sciences, Royal Museum for Central Africa, Tervuren

Public defence: 27 June 2011

Landslides are well-known processeses that hamper sustainable development efforts, particularly in developing countries where extreme poverty is already a household to societal problems. Though a worldwide problem, landslides remain enigmatic especially with regards to their geometry, causative factors, triggering mechanisms, and the relationship between triggering factors, slide occurrence and the susceptibility of any area to mass wasting phenomena. This thesis presents an inventory and thorough analysis of small-scale devastating landslides that occurred in recent years around the city of Limbe at the base of Mt Cameroon.

A multidisciplinary approach was adopted in order to understand the complex and multi-phase nature of landslide processes. This involved integrating results of traditional field mapping, rainfall measurements, analyses of geotechnical properties of soils, soil mineralogy and soil geochemistry to get an idea of the processes and mechanisms involved in landslide initiation and mobilisation. From these results, two conceptual models are proposed to explain the occurrence of landslides affecting areas populated by vulnerable people. The thesis thus provides first-hand field-measured geometric characteristics of landslide scars and systematically documents and quantifies for the first time the overall features of volume-limited devastating slides around Limbe. Hence, it provides constraints for modelling, monitoring and remediation efforts that might be applied in other areas affected by similar small-scale failures.

Geotechnical and mineralogical characterisation suggests that slope failure within the study area is enhanced by human intervention through anarchical construction and slope undercutting whereas natural slope failure is generated as a result of fracture permeability. This implies that in the absence of external factors the slopes within the study area would generally remain stable for long periods. This study suggests that understanding of the triggering processes and the relationship between triggers and slide occurrence could be improved through more accurate recording of landslide timing and the corresponding triggering events. This knowlegde can be used in landslide susceptibility assessment which is one of the most significant achievements of this thesis, and in 
the development of early-warning systems that might enable a reduction of the number of casualties and of economic loss from future landslide phenomena.

The findings from the present study have generic value and can be used to tackle small-scale slope instability problems elsewhere in the subtropics.

\section{References}

Che, V.B., Kervyn, M., Ernst, G.G.J., Trefois, P., Ayonghe, S., Jacobs, P., Van Ranst, E., Suh, C.E.Systematic documentation of landslide events in Limbe area (Mt Cameroon Volcano, SW Cameroon): Geometry, controlling and triggering factors. (Natural Hazards, doi: 10.1007/siro69-011-9738-3).

Che ,V.B., Kervyn, M., Suh, C.E., Ernst, G.G.J., del Marmol, M.-A., Trefois, P., Jacobs, P. Landslide susceptibility assessment in Limbe region (SW Cameroon) through a field calibrated seed cell and information value method (Catena, in revision). 